\title{
Bantuan Luar Negeri dan Pembangunan Desa: Efektivitas Participatory Irrigation Sector Project (PISP) di Desa Sumber Pucung, Kabupaten Malang
}

\author{
Mubammad Fandiaz, Al Akbar', Arief Setiawan ${ }^{2}$ \\ Universitas Brawijaya
}

\begin{abstract}
This research examines the effectiveness of HIPPA (Himpunan Petani Pemakai Air) in Sumberpucung Village, Malang Regency, after the implementation of PISP (Participatory Irrigation Sector Project) funded by ADB and the Dutch Government. The effectiveness will be measure through participation or a participatory approach. This research finds that a low level of participation in the HIPPA organization is due to power, structure, and individual motivations. The results of this research are the stagnancy of the HIPPA organization as a medium for participatory irrigation projects in the village.
\end{abstract}

Keywords: foreign aid, irrigation, water management, PISP, village

\section{PENDAHULUAN}

Bantuan luar negeri atau lebih populer dengan istilah development assistance, technical assistance, technical cooperation, atau foreign aid pada masa awal kemunculannya hanya fokus pada pemberian sejumlah modal dalam bentuk uang kepada negara penerima (recipient) untuk rekonstruksi pasca perang (Riddel, 2007: 195). Tetapi seiring berjalannya waktu, bantuan luar negeri tidak hanya ditandai dengan transfer modal atau capital flow semata. Bantuan luar negeri kontemporer saat ini juga menyertakan nilai-nilai (value), adjustment, dan conditionalities tertentu dalam aktivitasnya (Tarp, 2006: 1-3). Namun saat Structural Adjustment Program (SAP) diimplementasikan, hubungan negara utara dan selatan memburuk karena terlalu memberatkan negara berkembang dan negara miskin dan bantuan luar negeri banyak dikritik hanya sebagai alat untuk mencapai kepentingan negara donor (Khagram, 2002: 139). Akibat globalisasi, muncul aktivitas-aktivitas transnasional yang membuat kepopuleran aktor transnasional non-negara tinggi, salah satunya NGO dan Civil Society Organisation (CSO) yang mengakibatkan strategi dan formula bantuan luar negeri berubah. Konsep dan nilai seperti good governance, social capital, dan participation hadir memberikan formula yang dibutuhkan untuk mengatasi dan melengkapi kebutuhan arsitektur bantuan luar negeri.

Partisipasi menjadi salah satu konsep yang paling sering digunakan dalam implementasi bantuan luar negeri dan pembangunan. Pada awalnya konsep ini hadir sebagai jawaban atas kritik teori pembangunan tradisional yang menerapkan implementasi model topdown yang dianggap tidak memberi dampak positif secara keseluruhan kepada resipien (Claridge, 2004: 17). Partisipasi hadir dengan membawa model bottom-up yaitu memusatkan perhatian pembangunan pada individu (people-centred). Model pembangunan dengan top-down approach yang menekankan pada makroekonomi untuk menggenjot perekonomian suatu negara dianggap tidak terlalu berhasil di banyak negara dunia ketiga (Tandon, 2008: 98). Menurut Lane, perkembangan pada dunia ketiga memerlukan peran dari masyarakat dalam implementasi proyek yang bertujuan untuk pelaksanaan proyek dapat efisien serta diterima oleh masyarakat (objek proyek tersebut) (Lane, 1995: 181). 
Salah satu proyek bantuan luar negeri yang mengimplementasikan nilai partisipasi adalah Participatory Irrigation Sector Project (PISP). PISP adalah proyek bantuan luar negeri yang didanai oleh Asian Development Bank (ADB) dan Pemerintah Belanda (ADB, 2008: 14). Tujuan utama proyek ini adalah mencapai desentralisasi pengelolaan sistem irigasi berbasis keberlanjutan dan kenaikan produksi pertanian. Program ini diselenggarakan pada enam provinsi di Indonesia antara lain Banten, Provinsi Lampung, Jawa Barat, Jawa Timur, Jawa Tengah, dan Sulawesi Selatan. Inti pelaksanaan bantuan luar negeri ini ialah untuk mereformasi sistem irigasi yang ada di Indonesia dari yang menggunakan top-down approach yang terpusat ke arah yang lebih terdesentralisasi.

Program bantuan teknis PISP memiliki long-term Objectives atau tujuan jangka panjang berupa desentralisasi sistem irigasi partisipatif dan tujuan pendeknya adalah peningkatan ekonomi secara inklusif ditandai dengan penurunan angka kemiskinan di daerah (ADB, 2008: 16). Sementara Output dari proyek ini ada tiga yaitu: (1) sistem informasi manajemen sumber daya air ditingkatkan, (2) pemberdayaan dan peningkatan kapasitas Perkumpulan Petani Pemakai Air (P3A), (3) kinerja pengairan secara keseluruhan ditingkatkan, (4) kapasitas kabupaten untuk pengelolaan tanggung jawab irigasi yang ditingkatkan.

Dalam logframe proyek PISP, salah satu outcome adalah keberlanjutan desentralisasi sistem irigasi partisipatif. Untuk mewujudkannya, PISP memiliki aktivitas proyek berupa pendayagunaan masyarakat lokal (petani) dalam tata kelola irigasi. Salah satu bentuknya ialah setiap daerah target proyek mengharuskan pembentukan suatu organisasi kemasyarakatan di bidang irigasi yang memiliki dasar hukum (ADB, 2008: 3). Organisasi kemasyarakatan itu dicontohkan dengan pembentukan P3A atau biasanya di Jawa Timur lebih populer dengan sebutan Himpunan Petani Pemakai Air (HIPPA). PISP mengakomodasi pembentukan HIPPA dan memberikan pelatihan dan pemberdayaan kepada para anggotanya. Salah satu komponen proyek PISP adalah pembentukan, peningkatan kapasitas, dan pemberdayaan HIPPA. HIPPA diberikan pengetahuan dan wawasan perihal hak dan tanggung jawab mereka dalam sistem irigasi partisipatif.

Salah satu bentuk partisipasi HIPPA dalam proyek PISP adalah keterlibatan mereka dalam pengelolaan jaringan irigasi di tingkat tersier. HIPPA diberi wewenang untuk ikut menyuarakan usulan, menentukan, dan bertindak sendiri perihal tata kelola irigasi yaitu O\&P. Pengelolaan irigasi (operasional dan pemeliharaan) di tingkat jaringan irigasi tersier menjadi tanggung jawab HIPPA berdasarkan Undang Undang (UU) no. 7 tahun 2004 mengenai Sumber Daya Air (SDA). UU SDA tersebut merupakan hasil reformasi pemerintah untuk mempersiapkan landasan hukum bagi proyek PISP sebagai wujud keseriusan pemerintah tentang reformasi sistem irigasi. Hal tersebut membuat organisasi masyarakat petani daerah (HIPPA) harus aktif dan responsif agar pengelolaan irigasi terus berjalan atau berkelanjutan.

Setelah proyek ini berakhir, desentralisasi pengelolaan irigasi di tingkat tersier tetap menjadi wewenang HIPPA. HIPPA mempunyai tanggung jawab untuk melanjutkan pengelolaan irigasi partisipatif yang sebelumnya diprakarsai oleh bantuan luar negeri PISP. Bentuk pengelolaan partisipatifnya ialah memberikan usulan dan ikut melaksanakan teknis pelaksanaan yang berkaitan dengan O\&P di tingkat jaringan irigasi sekunder dan tersier. Akibat dari tanggung jawab tersebut membuat HIPPA juga harus berkembang dalam hal pengorganisasian. Tetapi yang terjadi dalam dokumen evaluasi pasca proyek PISP, pengelolaan irigasi partisipatif tidak sustain akibat ketidakmampuan HIPPA untuk melaksanakan dan melanjutkan apa yang telah menjadi tanggung jawabnya tersebut.

Permasalahan tersebut juga dapat ditemukan pada tata Kelola irigasi Desa Sumberpucung, Kabupaten Malang, daerah irigasi Molek. HIPPA yang dibentuk dengan tujuan memaksimalkan air di daerah tersebut justru memiliki masalah organisasi di dalamnya, salah satunya adalah masalah keanggotaan HIPPA dimana dalam pelaksanaan aktivitas 
organisasi tersebut, menuntut adanya iuran secara rutin pemanfaatan sumber daya air yang menjadi kewenangan HIPPA atau bisa disebut IPAIR. Dengan adanya IPAIR diharapkan dapat meningkatkan kapasitas organisasi dan memperbaiki atau memelihara saluran irigasi yang menjadi kewenangan HIPPA tersebut. namun pada kenyataannya iuran tersebut tidak berjalan pada pasca proyek PISP dan akhirnya HIPPA bergantung pada pemerintah lagi dalam perbaikan dan pemeliharaan saluran irigasi. Akibat permasalahan organisasi di HIPPA membuat pengelolaan irigasi tidak maksimal. Pengelolaan irigasi tidak maksimal dibuktikan dengan klasifikasi pengelolaan irigasi HIPPA/GHIPPA/IHIPPA menurut Peraturan Menteri (Permen) nomor 12 tahun 2015 mengenai Eksploitasi dan Pemeliharaan Jaringan Irigasi (Permen PUPR 12/2015). Ada empat klasifikasi yaitu pemula, muda, madya, dan mandiri. Klasifikasi ini diukur berdasarkan tingkat partisipasi HIPPA dalam pengelolaan irigasi. Ada 5 indikator yaitu pemikiran awal, pembentukan putusan, pembiayaan pelaksanaan kegiatan, SDM, dan teknis penyelenggaraan. Berdasarkan pra-penelitian yang dilakukan penulis bahwa HIPPA Sidodadi termasuk dalam klasifikasi pemula. Padahal amanat PISP, guna membuat proyek ini sustainable mengharapkan partisipasi dari unsur masyarakat di organisasi HIPPA. Namun pada kenyataannya HIPPA Sidodadi di Desa Sumberpucung, Kabupaten Malang tidak berkembang pasca proyek PISP. Maka dari itu, tulisan ini akan membahas alasan organisasi HIPPA tidak berkembang pasca proyek PISP.

\section{KERANGKA PEMIKIRAN}

Diana Suhardiman dalam jurnalnya yang berjudul "Bureaucratic Design: The Paradox of Irrigation Management Transfer in Indonesia" yang menjadi rujukan studi terdahulu menitikberatkan pada kata kunci manajemen irigasi dan berdasar pada implementasi Irrigation Management Transfer (IMT) di Indonesia periode 1995-2006. Tulisan ini membahas tentang implementasi IMT yang diprakarsai oleh WB lewat program WATSAL tidak berjalan sesuai harapan. Suhardiman menemukan ada semacam resistensi dari para objek penerima bantuan luar negeri WATSAL yang mana mereka setengah hati membagi dan memberikan kekuasaan tata kelola air pada pihak lain (Suhardiman, 2008: 396).

Dalam tulisan ini dijelaskan mengenai IMT sebagai transfer manajemen irigasi dari otoritas yang tinggi ke otoritas yang lebih rendah untuk memaksimalkan efektifitas manajemen irigasi nasional. Intinya ialah pemerintah pusat sebagai otoritas yang dulunya sebagai pengontrol tunggal tata kelola air, harus rela kekuasaannya terdesentralisasi ke institusi/badan yang lebih rendah level hierarki-nya seperti Perkumpulan Petani Pemakai Air (P3A), Balai Sungai, dan Dinas daerah. Suhardiman dalam penelitiannya ini meneliti keterkaitan agensi internasional sebagai donor dan juga nilai-nilai global yang dibawa oleh mereka dengan politik domestik (dinamika institusi irigasi Indonesia dan dinamika politik nasional pasca reformasi) (Suhardiman, 2008: 9).

Selain itu, konsep partisipasi juga ada dalam kerangka konseptual IMT yang terdapat di dalam tulisan Suhardiman, tetapi Program WATSAL milik WB hanya menyasar pada transfer manajemen tata kelola irigasi yang membutuhkan hampir kurang lebih 6 tahun lamanya untuk membuat regulasi dan kebijakan tentang desentralisasi tata kelola pengairan di Indonesia. Pelaksanaan nilai partisipasi dalam tata kelola air sebenarnya baru disinggung ketika Proyek PISP dari ADB berjalan di tahun 2006 ketika WATSAL memasuki fase penyelesaian program. Maka dari itu Penulis menggunakan tulisan Suhardiman untuk membantu melihat latar belakang dinamika politik dalam reformasi tata kelola irigasi di Indonesia pasca reformasi karena Indonesia ketika masa 2000-2008 adalah masa transisi pembangunan, banyak terjadi reformasi struktural, kebijakan, regulasi dalam institusi pemerintah baik pusat maupun daerah. 


\section{Partisipasi}

Konsep partisipasi memiliki genealogy yang panjang dan cukup bervariasi dalam pemikiran dan praktik kajian pembangunan. Konsep ini terus mengalami perkembangan dan perubahan akibat adanya aliran baru, agenda institusional, dan keadaan politik yang berubah (Hickey dan Mohan, 2004: 5). Konsep partisipasi seringkali digunakan dalam ilmu pembangunan dan politik. Konsep ini merupakan salah satu dari strategi global yang menentang tren top-down approach yang mana pada era 1950-an mendominasi kajian pembangunan (Claridge, 2004: 17). Konsep ini mengarahkan ke metodologi yang lebih sensitif yaitu memusatkan pada keterlibatan konteks lokal dalam implementasi program pembangunan (Storey 1999).

Dominasi pendekatan top-down terhadap pembangunan sebagian besar merupakan hasil dari teori modernisasi yang dominan pada 1960-an (Lane, 1995). Teori modernisasi percaya bahwa satu-satunya solusi untuk berbagai negara berkembang untuk berkembang adalah dengan pertumbuhan ekonomi masif seperti yang dilakukan oleh negara-negara barat (hal. 181). Teori yang mendominasi pada penekanan top-down approach dan state-centic telah banyak dikritik dan akhirnya melahirkan teori-teori pembangunan alternatif akibat kegelisahan yang dirasakan negara-negara dunia ketiga. Dari sudut pandang modernisasi, partisipasi berarti keterlibatan masyarakat dalam pelaksanaan proyek dengan tujuan meningkatkan penerimaan dan efisiensi program (hal. 185).

Kesadaran pentingnya konsep partisipasi tumbuh dari kenyataan bahwa masyarakat miskin di berbagai belahan dunia benar-benar menderita akibat dari pembangunan yang ada sebelumnya (Holcombe, 1999). Holcombe melanjutkan bahwa setiap orang perlu dilibatkan dalam keputusan, implementasi, dan pemanfaatan pembangunan. Pemikiran Holcombe ternyata tidak jauh berbeda dengan Mompati dan Prinsen yang membuat membuat pengamatan serupa tentang keunikan individu sebagai entitas yang mampu memberikan kontribusi unik untuk pengambilan keputusan sehingga dapat memberikan dampak tersendiri bagi mereka (Mompati dan Prinsen, 2000: 625-630).

Partisipasi menjadi buzzword dalam kajian pembangunan yang selalu didengungkan di setiap pembicaraan tentang pembangunan. Menurut Lane partisipasi dipengaruhi oleh banyak kajian seperti pembangunan, ekonomi, politik dan lainnya (hal. 181). Akibatnya konsep ini memiliki karakteristik yang sangat luas, bervariasi dan kompleks karena posisi teoretis yang berbeda. Pada awal perkembangannya, konsep partisipasi lebih sering dipakai dalam ilmu politik untuk menjelaskan tentang keterlibatan masyarakat dalam sistem politik negara (Hickey dan Mohan, 2004: 6).

Konsep partisipasi di bidang pembangunan baru hadir ketika periode 1970- an ketika akibat industrialisasi membuat kaum marjinal semakin tertindas. Program-program pembangunan dianggap terlalu fokus pada ekonomi makro saja dan kurang memperhatikan acceptance dan efektifitas program pembangunan bagi kaum marjinal. Lalu tren partisipasi selalu berubah mengikuti perkembangan zaman seiring adanya aliran-aliran baru, kondisi politik. Tetapi orang yang paling terkenal mempopulerkan metode partisipatif adalah Robert Chambers. Robert Chambers adalah orang pertama yang mempopulerkan metodologi atau tools penerapan konsep partisipasi untuk program pembangunan, harapannya agar masyarakat dapat menerima efek langsung dan ikut serta dalam aktivitas program pembangunan sehingga program tersebut efektif (Chambers, 1995: 30-32).

\section{Analisis Individu: Teori Frances Cleaver}

Cleaver mengkritik kerangka partisipasi yang diberikan oleh agensi pembangunan yang mengabaikan unsur kultural, powver relation, dan local identities (Cleaver, 1999: 612). Cleaver mengambil ide pemikiran dari teori strukturasi Giddens yang menyatakan bahwa dalam 
konteks pembangunan, struktur bukan bersifat eksternal melainkan bersifat internal bagi individu (Giddens, 1984). Nyatanya individu-lah yang mengontrol struktur tersebut. Cleaver berpendapat bahwa perlu memahami sifat diluar proyek pembangunan dari kehidupan masyarakat, keterkaitan ekonomi yang kompleks yang membuat dampak di satu bidang mungkin dirasakan di daerah lain dan potensi konsekuensi yang tidak diinginkan yang timbul dari intervensi atau tindakan lainnya (Cleaver, 1999: 599).

Cleaver menyarankan untuk menerapkan konsep partisipasi berdasarkan 2 poin yaitu: analisis model of individuals dan analisis power and structure. Analisis individu berkaitan tentang hal-hal seperti identitas lokal, insentif, negosiasi dalam proses pembangunan adalah instrumen penting dalam penerapan nilai partisipatif menurut Cleaver. Analisis ini berkaitan dengan cost-benefit dan penggunaan local identities sebagai instrumen menganalisis individu (masyarakat). Cleaver menyatakan bahwa harus diperhatikan juga oleh para agensi pembangunan bahwa tidak bisa menyamaratakan individu. Individu belum tentu akan secara sukarela ikut berpartisipasi dalam suatu proyek melalui keikutsertaannya dalam suatu institusi karena masing-masing individu memiliki self-interest dan motivasi yang berbeda-beda. Tujuan pembentukan institusi lokal yang ada dalam proyek pembangunan seperti PISP adalah mengurangi biaya transaksi individu, dan menyamakan tujuan (collective action) sehingga individu/masyarakat dapat dikontrol sehingga memaksimalkan hasil proyek pembangunan dianggap Cleaver sesuatu yang kurang tepat.

Analisis individu didasarkan atas pemikiran Cleaver di bagian models individual yang menyatakan bahwa dalam pendekatan fungsional suatu proyek, individu hanya dijadikan persyaratan atau disama-ratakan dengan proyek-proyek lain yang telah ada. Analisis individu didasarkan atas pemikiran Cleaver di bagian models individual yang menyatakan bahwa dalam pendekatan fungsional suatu proyek, individu hanya dijadikan persyaratan atau disamaratakan dengan proyek-proyek lain yang telah ada. untuk orang-orang yang berbagai tempat yang berbeda (cost-benefit), dan dari pertentangan dan masalah yang berhubungan dengan produksi dan reproduksi, usia, dan gender (hal. 607).

\section{Analisis Power dan Struktur: Teori Power Cube John Gaventa}

Gaventa dengan teori power cube miliknya menjelaskan bahwa konsep kekuasaan dapat membuka analisis mengenai citizen engagement terutama partisipasi (Gaventa, 2006: 23). Tingkat penerimaan masyarakat terhadap program kebijakan atau program pembangunan belum tentu tinggi. Pengaturan kelembagaan yang mengedepankan inklusi dan pro-poor nyatanya belum tentu membuat tingkat penerimaan masyarakat tinggi (hal. 23). Gaventa melihat bahwa hal tersebut lebih tergantung pada relasi sosial atau hubungan kekuasaan yang ada dalam realita dan struktur sosial di wilayah tersebut (hal.24). Power cube merupakan sebuah konsep untuk menganalisis kekuasaan menggunakan tiga dimensi yaitu spaces, places, shapes (Gaventa, 2004: 34).

Masalah atau fenomena partisipasi masyarakat yang ada dalam suatu kebijakan atau program pembangunan dapat dijelaskan menggunakan power cube. Teori ini menerangkan hubungan kekuasaan yang terbentuk pada tingkat atau daerah-daerah kekuasaan dengan menganalisis terkait ruang (spaces) yang dibentuk oleh para aktor. Ruang dipandang sebagai peluang, momen, dan wahana yang bisa mempengaruhi berbagai kebijakan, wacana, dan keputusan (Hickey dan Mohan, 2004: 35). Sementara itu dimensi shapes ialah bentuk kekuasaan yang mempengaruhi hubungan kekuasaan teritama pada pembentukan putusan (hal. 37). Dimensi terakhir adalah dimensi places yang merupakan dimana kontestasi kekuasaan itu berada, apakah di level global, nasional atau subnasional. Dalam teori kubus kekuasaan, ketiga dimensi kekuasaan dengan berbagai jenis dan warnanya tidak berdiri sendiri melainkan saling terkait dan bahkan saling mempengaruhi. 
Analisis berdasarkan tulisan Cleaver tentang teori institusionalis dalam diskursus partisipasi pembangunan. Intinya, analisis ini melihat hubungan rekursif antara struktur, agensi, dan individu (masyarakat). Struktur sosial oleh beberapa peneliti dianggap sebagai peluang dan kendala dalam implementasi pembangunan tetapi sangat sedikit yang berkenan untuk dianalisis. Keterkaitan antara individu, struktur dan institusi/agensi internasional yang ada saat ini adalah contoh model yang buruk. Hingga akhirnya cara alternatif didapatkan dengan fokus pada pembentukan organisasi aksi kolektif; mengorganisasi organisasi kemudian cara tersebut menjadi landasan utama dari pendekatan partisipatif untuk pembangunan yang ada saat ini.

Penelitian ini termasuk dalam jenis penelitian eksplanatif. Penulis telah menentukan bahwa unit analisis yang akan penulis gunakan adalah penjelasan eksplanatif dimana penulis akan menggunakan variabel dependen yang berimplikasi pada unit eksplanasi yang independen yang dimana unit analisis yang dipakai oleh penulis dalam penelitian ini adalah implementasi nilai partisipatif dalam proyek bantuan luar negeri PISP, kondisi tata kelola air paska program di dalam kurun waktu penelitian satu semester awal tahun 2019, dan desain proyek dari program PSIP. Penelitian ini akan berfokus pada fokus pada kelembagaan HIPPA Sidodadi sebagai objek bantuan. Teknik yang dipakai dalam tulisan ini yaitu studi pustaka (library research) dan terjun langsung mengamati (fieldwork). Data yang dikumpulkan bersifat data sekunder seperti buku, jurnal, koran, working paper, laporan termasuk skripsi/tesis/disertasi, ebook dan sumber kredibel lain dari internet. Selain textbook, penulis juga menggunakan data interview dari wawancara, forum group discussion, dan observasi. Penelitian ini menggunakan teknik analisis kualitatif.

\section{HASIL DAN PEMBAHASAN}

\section{Proyek Participatory Irrigation Sector Project (PISP)}

Proyek PISP merupakan program bantuan luar negeri di sektor irigasi dan pertanian yang merupakan inisiatif dari pemerintah Indonesia. Program ini memiliki tujuan untuk memperbaiki kondisi agrikultur baik dalam segi manajemen dan operasionalnya, dan dalam produktivitasnya. Dana proyek PISP bersumber dari dana bantuan (loans) dari ADB, dana hibah dari Pemerintah Belanda, dan dari APBN. Rincian proyek PISP bisa dijabarkan sebagai berikut: (1) Uraian proyek; (2) Pembiayaan; (3) Tata laksana; (4) Monitoring dan evaluasi; dan (4) Pelaporan. Proyek PISP mencakup 25 kabupaten yang terletak di 6 provinsi yaitu: Lampung, Banten, Jawa Barat, Jawa Tengah, Jawa Timur, dan Sulawesi Selatan. Salah satunya di Kabupaten Malang, Jawa Timur. Ada total 14 Daerah Irigasi (DI) di Kabupaten Malang yang masuk dalam Proyek PISP.

Tujuan jangka panjang PISP adalah mengembangkan laju ekonomi dan menurunkan angka kemiskinan di pedesaan di 25 kabupaten di Indonesia. Tujuan pendek proyek ini adalah desentralisasi pengelolaan jaringan irigasi secara berkelanjutan, dan menumbuhkan hasil panen pada lahan pertanian beririgasi. Proyek ini menggunakan pendekatan Pengelolaan Irigasi Partisipatif (PPSIP) yang mempertimbangkan keterbatasan kabupaten dalam pendanaan, serta berbagai kemampuan kelembagaan, teknis, dan manajemen. Proyek ini terdiri dari tiga komponen yaitu: (a) Pengelolaan irigasi; (b) Informasi Sumber Daya Air dan data manajemen; dan (c) Koordinasi dan Monitoring Proyek.

Pertama, pengelolaan irigasi, komponen proyek ini terdiri dari: peningkatan kemampuan kabupaten, peningkatan kemampuan, keberlanjutan pengoperasian prasarana irigasi, dan dukungan untuk pertanian irigasi. Proyek ini mengembangkan kemampuan kelembagaan pemerintah dan kemampuan teknik 25 kabupaten agar dapat secara efektif melaksanakan tanggung jawab pengelolaan irigasi, sesuai dengan kebijakan nasional dan peraturan-peraturan tentang irigasi. Kedua, Informasi Sumber Daya Air dan Data 
Manajemen, Komponen ini memperbaiki dan memperluas pengoperasian sistem manajemen informasi sumber daya air dan fasilitas ini dibentuk di Ditjen SDA dengan cabang di provinsi dan kabupaten, menyiapkan akses data yang bermutu serta informasi ke berbagai sektor. Pengaturan kelembagaan untuk pengelolaan Pusat Data SDA (WRDC) yang ada di kantor Ditjen SDA akan ditingkatkan, dan WRDC akan diintegrasikan ke dalam struktur organisasi regular di Ditjen SDA.

Metodologi pelaksanaan proyek dan penerapannya diformulasikan dengan mengikuti prinsip-prinsip: Pendekatan sesuai permintaan. Penerapan pendekatan sesuai permintaan harus sejalan dengan prinsip otonomi daerah dan mengakomodasi keterbatasan pendanaan yang berbeda pada setiap kabupaten, kemampuan kelembagaan serta kemampuan teknis dan manajemen. Prinsip berikutnya adalah pilihan bagi penerima manfaat. Proyek ini dirancang untuk memberikan porsi pengawasan yang besar kepada kabupaten dan P3A dengan menawarkan kepada mereka kewenangan untuk menentukan kegiatan apa yang mereka inginkan, kapan dibutuhkan, dimana dan bagaimana mendapatkan jasa pelayanannya. Instrumen untuk hal ini tertuang dalam menu jasa pelayanan, yang mana setiap kabupaten dapat dipilih, sampai kepada biaya maksimum yang dibutuhkan, paket kegiatan yang cocok dan paling efektif untuk mendukung program kabupaten. Selanjutnya ada prinsip transparansi dan akuntabilitas. Dua hal ini akan didapatkan melalui berbagai langkah. Sebagaimana telah diuraikan diatas, kegiatan proyek dimulai dengan kampanye publik serta perencanaan partisipatif pada tingkat kabupaten dan daerah irigasi. Terakhir, ada prinsip keterlibatan multi-stakeholder. Proyek ini mempromosikan keterlibatan banyak pihak terkait dalam pelaksanaan kegiatan proyek terutama dalam hal penyediaan jasa kepada organisasi kemitraan.

Proyek ini memiliki dua tipe bantuan, yaitu peningkatan kemampuan/penguatan kelembagaan, dan bantuan prasarana irigasi. Pertama, salah satu tujuan utama PISP adalah peningkatan kemampuan dan penguatan kelembagaan bagi pemerintah kabupaten, P3A dan kelompok tani yang terlibat. PISP dan proyek Bank Dunia WISMP merupakan programprogram irigasi pertama yang dilaksanakan setelah dikeluarkannya UU sumber daya air yang baru dan peraturan pemerintah tentang irigasi (PP No.20/2006). Oleh karena itu, kedua proyek tersebut akan memimpin dalam pembuatan suatu curriculum national untuk pelaksanaan PPSIP, yang akan dilaksanakan dalam kerangka PISP dan WISMP. Mayoritas komponenkomponen kedua proyek tersebut dalam melaksanakan PPSIP akan diharmonisasikan. Kedua, Proyek ini bertujuan untuk menghentikan siklus penundaan pemeliharaan sistem irigasi dengan cara perbaikan atau penggantian prasarana irigasi, yang sangat penting untuk kinerja daerah irigasi. Usul untuk perbaikan pekerjaan harus datang dari P3A yang kemudian diperiksa oleh dinas SDA kabupaten dan disahkan oleh Komir secara kompetitif. Untuk setiap daerah irigasi, usulan perbaikan harus dipersiapkan melalui kerjasama P3A dan dinas SDA.

Proyek ini terdiri dari 2 tipe pekerjaan sipil yang tujuannya menjaga prasarana jaringan irigasi yang berkelanjutan, yaitu: Sustainable Replacement of Rehabilitation (SRR) dan Rehabilitasi. Total estimasi biaya proyek sebesar $\$ 126$ juta, tetapi biaya proyek aktual pada saat penutupan proyek adalah $\$ 127,5$ juta. Biaya tersebut terdiri dari $\$ 29,1$ juta dalam valuta asing dan $\$ 98,4$ juta dalam mata uang lokal. ADB membiayai $\$ 24,4$ juta dalam bentuk valuta asing dan $\$ 49,9$ juta dalam bentuk mata uang rupiah, sedangkan Pemerintah Belanda membiayai $\$ 4,6$ juta dalam bentuk valuta asing dan $\$ 10,4$ juta dalam bentuk mata uang rupiah (ADB, 2014). Sisanya ditanggung oleh Pemerintah Indonesia senilai $\$ 31,9$ juta dalam bentuk mata uang rupiah. Para penerima manfaat juga menyumbang $\$ 6,2$ juta dalam bentuk mata uang lokal. 
Proyek ini dibiayai dari 4 sumber pendanaan, yaitu: pinjaman dari ADB dengan kategori Ordinary Capital Resources (ODR), pinjaman dari ADB dengan kategori Asian Development Fund (ADF), hibah dari Pemerintah Belanda, dan kontribusi dari Pemerintah Indonesia (ADB, 2012). ADB dan Pemerintah belanda membiayai sekitar 60\% dari total biaya proyek. Hal ini dikarenakan sifat pekerjaan proyek yang terutama ditujukan untuk penguatan kelembagaan di kabupaten dan P3A, skala kecilnya perbaikan dan rehabilitasi daerah irigasi. Proyek diklasifikasikan sebagai proyek penanggulangan kemiskinan dan diharapkan memberikan kontribusi secara signifikan terhadap pemberantasan kemiskinan dan perbaikan kondisi kehidupan masyarakat di lokasi proyek.

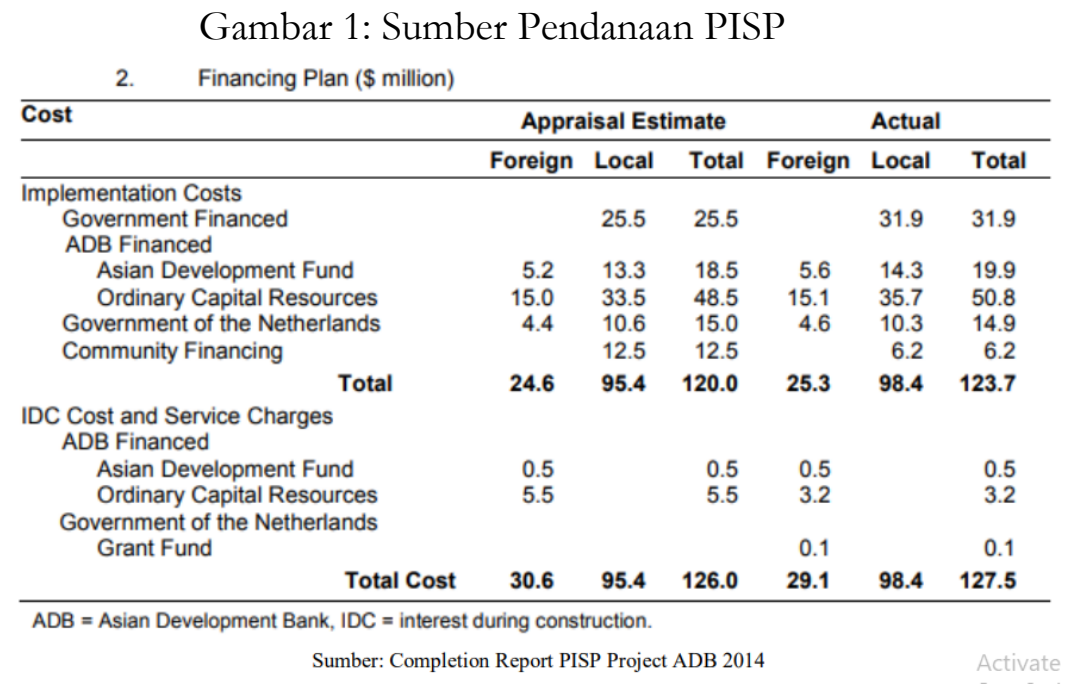

Tujuan jangka panjang PISP adalah desentralisasi pengelolaan irigasi partisipatif. Untuk membuat agar apa yang telah dicapai PISP tetap berlanjut maka harus ada strategistrategi tertentu yang dipersiapkan. Dalam desain proyek PISP memang tidak tercantum tentang exit strategy pasca PISP berakhir tetapi dalam dokumen proyek dicantumkan tentang beberapa poin agar pengelolaan irigasi yang telah dicapai pada proyek PISP berkelanjutan. Ada tiga poin yang penulis dapat berdasarkan hasil riset dokumen-dokumen proyek yaitu pelaksanaan RP2I secara kontinu oleh kabupaten, pelaksanaan program-program pemberdayaan $\mathrm{P} 3 \mathrm{~A}$, dan pembentukan lembaga-lembaga pendukung pengelolaan irigasi partisipatif.

Rencana Pengembangan dan Pengelolaan Irigasi (RP2I) termasuk dalam salah satu komponen proyek PISP yaitu komponen pengelolaan irigasi di sub-bab peningkatan kemampuan daerah (ADB, 2008: 7). RP2I adalah alat perancangan wacana yang dibutuhkan oleh Kabupaten dalam mengimplementasikan kebijakan dan strategi rekonstruksi daerah di bidang pertanian, serta Pengelolaan Irigasi Secara Partisipatif (PPSIP). Pengembangan dan Pengelolaan Irigasi secara Partisipatif (PPSIP) adalah pedoman nasional tentang pengelolaan irigasi yang termuat dalam Permen PU No.30 Tahun 2007 mengenai Sistem Irigasi Partisipatif. RP2I bertujuan untuk mewujudkan pertumbuhan kesejahteraan masyarakat petani, dan keberlanjutan sistem irigasi di Kabupaten (RP2I, 2009). RP2I dirancang sebagai dasar perencanaan jangka menengah sampai jangka panjang dalam program pemerintah daerah di sektor irigasi yang mana perencanaan ke depan adalah untuk periode 5 tahunan berdasarkan kebutuhan perbaikan untuk memperbaiki keberlanjutan kondisi fisik dan keuangan sistem irigasi dengan pendekatan partisipatif untuk pengelolaan irigasi. RP2I 
dirancang juga sebagai tindak lanjut dari beberapa kebijakan pemerintah terkait pengelolaan irigasi.

\section{Gambar 2: Kerangka RP2I}

RP2I sebagai Tindak Lanjut dari beberapa Kebijakan Pemerintah

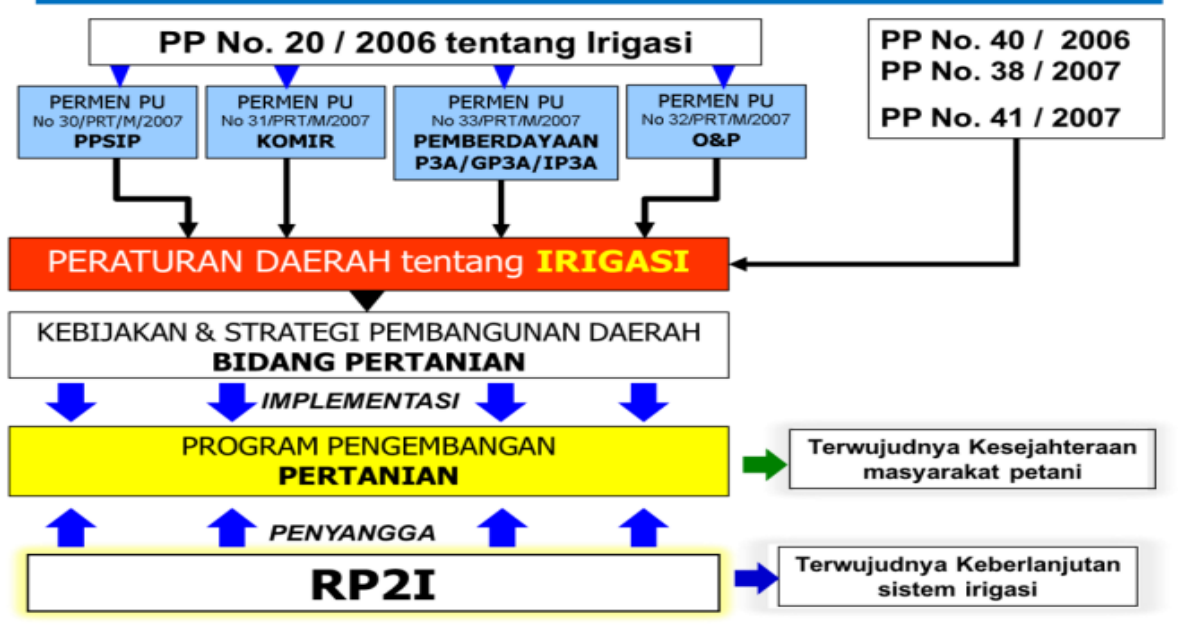

Sumber: Dokumen Strategi Perencanaan dan Perumusan RP2I dari Dinas Pengairan Kab. Malang

Terdapat 8 prinsip dalam penyelenggaraan RP2I yaitu:

1) RP2I berisi kerangka program pengelolaan irigasi tingkat Kabupaten dan merupakan bagian dari Decision Support System Program Pengembangan Pertanian di Kabupaten yang bersangkutan. RP2I harus melingkupi semua DI yang ada dalam Kabupaten yang bersangkutan;

2) RP2I disusun untuk periode 5 tahun, dan dievaluasi implementasinya setiap akhir tahun anggaran;

3) RP2I disusun oleh Kelembagaan Pengelolaan Irigasi (KPI);

4) Penyusunan RP2I harus menyertakan instansi SDA tingkat Kabupaten, Provinsi dan Pusat, melalui MOU;

5) RP2I disusun dengan mengoptimalkan peran P3A/GP3A/IP3A;

6) RP2I disusun dengan memaksimalkan koordinasi antar Instansi Pemerintah bidang irigasi, melalui Komir;

7) RP2I disusun berdasarkan asas kemandirian, dengan titik berat pada terciptanya keberlanjutan sistem irigasi;

8) RP2I merupakan acuan dasar, dapat disesuaikan dgn kebutuhan Kabupaten.

Kabupaten Malang sendiri di tahun 2009 telah mempertimbangkan merancang RP2I sesuai amanat dari PISP yang berakhir pada tahun 2009. Workshop, pelatihan, dan seminar telah dilaksanakan yang diikuti oleh beberapa bidang pemerintahan (Bappeda, Dinas Pertanian, Dinas Pengairan). Tetapi dalam implementasi kebijakan tentang pengelolaan irigasi, pemerintah daerah dibantu Dinas Pengairan dan Dinas Pertanian masih belum mengimplementasikan RP2I dalam kebijakan dan strategi pengembangan dan pengelolaan irigasi. Memang sudah terdapat Perda Kab. Malang nomor 8 tahun 2008 mengenai irigasi yang menyinggung perihal pengelolaan aset irigasi secara berkelanjutan. Tetapi belum secara jelas menyinggung secara utuh RP2I. Perda tersebut hanya mengatur tentang sistem inventarisasi pengelolaan dan pengembangan irigasi di semua daerah irigasi Kab. Malang dan tidak memperbarui rencana 5 tahunan perihal pengelolaan irigasi berkelanjutan. 


\section{Tata Kelola Irigasi di Desa Sumberpucung (HIPPA Sidodadi)}

Sistem irigasi Indonesia modern kini mencangkup jaringan irigasi utama (Jitut), dan jaringan irigasi desa (Ji.des) (Ansori.et.al, 2018: 2). Jitut merupakan jaringan irigasi penting berupa saluran, bangunan air, bangunan ukur, bendung, dan inventaris irigasi lainnya yang berkaitan dengan irigasi primer dan sekunder. Sementara Jides, pada umumnya semua jaringan irigasi di tingkat tersier. Saluran jaringan irigasi ditentukan oleh perbedaan luas daerah irigasinya. Jaringan pembawa irigasi atau saluran irigasi memiliki 4 jenis jika dilihat melalui perbedaan luas daerah irigasi antara lain:

1) Saluran pembawa primer Saluran pembawa primer adalah saluran yang mengambil air langsung dari sumber air utama (sungai, waduk, bendung, dan lainnya). Saluran primer membawa air dari jaringan utama ke saluran sekunder dan petak-petak tersier yang diari.

2) Saluran pembawa sekunder Saluran pembawa sekunder adalah saluran yang membawa air dari saluran primer ke saluran-saluran tersier yang ternasuk dalam petak sawah dan sistem irigasi jaringan tersebut.

3) Saluran pembawa tersier Saluran ini berfungsi untuk membawa air dari saluran sekunder ke petak-petak sawah yang merupakan gabungan dua atau lebih petak kwartet.

4) Saluran pembawa kwartet Saluran kwartet menjadi saluran terakhir dalam suatu jaringan irigasi yang fungsinya memberikan air untuk satu kelompok irigasi. Satu kelompok irigasi tersebut bisa juga dikatakan sebagai satu petak kwartet.

Tata kelola air di HIPPA Sidodadi merupakan jaringan irigasi desa (Jides) yang mana berada dalam daerah irigasi (DI) Molek. Pada umumnya satu desa memiliki satu HIPPA yang memiliki satu jaringan irigasi tersier. Begitu juga yang terdapat di Desa Sumberpucung yang mana memiliki satu HIPPA yaitu HIPPA Sidodadi. Desa Sumberpucung bertempat di Kecamatan Sumberpucung, Kabupaten Malang, Jawa Timur dengan letak geografisnya di $8^{\circ} 09^{\prime 2} 27,8^{\prime \prime}$ - $-112^{\circ} 29^{\prime}$ 27,4”E. HIPPA Sidodadi berdiri pada tanggal 21 Juli 1999 oleh para petani di Desa Sumberpucung. Pada saat itu kelompok ini masih bersifat kolektif sukarela, yang mana keanggotaannya tidak mengikat dan berdasarkan asas kesukarelaan (volunteer). Pada tanggal 27 April HIPPA Sidodadi terbentuk secara resmi sebagai organisasi perkumpulan petani pemakai air yang disahkan oleh Camat Sumberpucung pada saat itu Dra. Kamti Astuti, dan Kepala Desa Sumberpucung, Tamat (AD/RT HIPPA Sidodadi, 2010: 1). HIPPA Sidodadi mempunyai wilayah kerja meliputi saluran irigasi di DI Molek dengan luas baku sawah seluas 350 ha.

Tugas dari HIPPA Sidodadi dalam pengelolaan air di wilayah irigasinya meliputi dari:

1) Ikut mengelola air jaringan irigasi secara tepat guna dan berhasil guna dengan memperhatikan unsur keadilan sesama anggota

2) Ikut berpartisipasi dalam rekonstruksi dan rehabilitasi saluran sehingga jaringan irigasi tersebut bisa tetap terjaga kelangsungan fungsinya

3) Menetapkan dan mengelola iuran dari anggota berupa uang dan atau tenaga untuk pendayagunaan air irigasi dan memelihara jaringan irigasi dalam wilayah kerjanya serta berbagai upaya pengembangan perkumpulan sebagai suatu organisasi

4) Membimbing dan menagwasi anggota agar mentaati semua peraturan yang memiliki relasi dengan pemakai air oleh Pemerintah Pusat, Daerah, ataupun HIPPA

5) Merekonstruksi berbagai upaya ekonomi guna pendayagunaan air irigasi dan kesejahteraan anggota

Keorganisasian HIPPA Sidodadi terdiri dari tiga elemen yaitu: Rapat anggota; Pengurus; Anggota. Rapat anggota ialah kekuasaan tertinggi dalam organisasi HIPPA Sidodadi. Semua keputusan yang telah disepakati dalam rapat anggota sifatnya absolut, dan mengikat bagi semua anggota. Rapat anggota minimal diselenggarakan dua kali setahun yaitu menjelang musim hujan $(\mathrm{MH})$ dan musim kemarau $(\mathrm{MK})$ tetapi rapat anggota juga bias 
dilaksanakan sewaktu-waktu bila memang diperlukan. Rapat anggota dapat diselenggarakan sewaktu-waktu bila didasarkan atas prakarsa pengurus, prakarsa atau saran tim Pembina HIPPA, dan permohonan dari 1/10 jumlah anggota. Rapat anggota mempunyai tugas dan wewenang yaitu: membentuk atau menentukan atau mengubah peraturan; membuat dan atau membubarkan pengurus; menentukan program kerja anggaran belanja; mengesahkan pertanggungjawaban pengurus; menentukan jenis dan besarnya iuran; menetapkan jenis pelanggaran dan sanksi.

Anggota HIPPA adalah semua yang mendapatkan manfaat dari saluran sekunder Y ke tersier Y.kr2 atau petak wilayahnya mendapatkan air irigasi dari sekunder Y di wilayah tersier Y.kr2. Setiap aggota berhak mendapatkan alokasi air sesuai dengan ketentuan pembagian air yang telah ditentukan oleh pejabat yang berwenang dan aturan atau jadwal yang telah ditentukan. Setiap anggota HIPPA juga wajib ikut melestarikan jaringan pengairan dengan membayar iuran air serta memenuhi ketentuan-ketentuan yang telah diucapkan dalam rapat anggota. Jika ada anggota yang menunggak atau telat dalam membayar iuran paling lambat satu bulan maka diberikan sanksi berupa penangguhan pengelolaan sawah pada periode tanam selanjutnya hingga melunasi iuran-nya tersebut.

\section{Permasalahan di HIPPA SIDODADI}

Berdasarkan indikator dari pemerintah dan observasi penulis di lokasi penelitian, tingkat partisipasi HIPPA Sidodadi bisa dikategorikan di tingkat pemula. Pemikiran awal dari HIPPA Sidodadi masih pasif, yaitu sebatas mendengar dan mengikuti semua arahan dari fasilitator (Dinas Pengairan dan BBWS Berantas). Dalam hal pengambilan keputusan perihal teknis irigasi (Rencana Tata Tanam, pemeliharaan dan operasional jaringan irigasi), HIPPA Sidodadi juga masih pasif. Contohnya mereka masih belum mau menerapkan RT'TG yang dianjurkan oleh dinas. Sementara untuk hal operasional dan pemeliharaan jaringan irigasi, tidak ada mekanisme resmi tentang bagaimana mereka terlibat dalam hal operasional dan pemeliharaan. Sumber Daya manusia di HIPPA Sidodadi juga masih kurang karena sebagian besar anggota masih belum mengetahui tentang keorganisasian (PSETK), dan juga pemahaman yang minim tentang irigasi. Teknis pelaksanaan seperti perawatan, inspeksi, dan pengaturan giliran air di HIPPA Sidodadi juga sangat minim. Hanya pengaturan giliran air yang secara rutin dilakukan di jaringan irigasi HIPPA Sidodadi sementara untuk inspeksi, perawatan masih belum berjalan.

Gambar 3: Tingkat Partisipasi dalam HIPPA

\begin{tabular}{|c|c|c|c|c|}
\hline \multirow[t]{2}{*}{ Indikator } & \multicolumn{4}{|c|}{ Tingkat Partisipasi HIPPA/GHIPPA/IHIPPA } \\
\hline & Pemula & Madya & Мaju & Mandiri \\
\hline $\begin{array}{l}\text { Pemikiran } \\
\text { Awal }\end{array}$ & $\begin{array}{l}\text { Mendengar } \\
\text { pasif }\end{array}$ & $\begin{array}{l}\text { Memberi } \\
\text { Usulan }\end{array}$ & $\begin{array}{l}\text { Usulan } \\
\text { Konkret }\end{array}$ & $\begin{array}{l}\text { Usulan } \\
\text { Konkret \& } \\
\text { Layak } \\
\text { dilaksanakan }\end{array}$ \\
\hline $\begin{array}{l}\text { Pengambilan } \\
\text { Keputusan }\end{array}$ & Menolak & Kesepakatan & Kerjasama & \begin{tabular}{|l} 
Mampu \\
Mengajukan \\
Alternatif
\end{tabular} \\
\hline $\begin{array}{l}\text { Pembiayaan } \\
\text { Pelaksanaan } \\
\text { Kegiatan }\end{array}$ & $\begin{array}{l}10 \% \\
\mathrm{AKNOP}\end{array}$ & $\begin{array}{l}25 \% \\
\text { AKNOP }\end{array}$ & $\begin{array}{l}35 \% \\
\text { AKNOP }\end{array}$ & $\begin{array}{l}50 \% \\
\text { AKNOP }\end{array}$ \\
\hline $\begin{array}{l}\text { Sumberdaya } \\
\text { Manusia } \\
\text { Pelaksana }\end{array}$ & Kurang & Sedang & Cukup & Mantap \\
\hline $\begin{array}{l}\text { Teknis } \\
\text { Pelaksanaan }\end{array}$ & Rutin & $\begin{array}{l}\text { Rutin \& } \\
\text { Berkala }\end{array}$ & \begin{tabular}{|l|} 
Rutin, \\
Berkala \& \\
Darurat
\end{tabular} & $\begin{array}{l}\text { Pemeliharaan } \\
\text { \& } \\
\text { Rehabilitasi }\end{array}$ \\
\hline
\end{tabular}


Permasalahan pertama pada HIPPA Sidodadi adalah permasalahan lembaga yang tidak berjalan sebagaimana mestinya. HIPPA Sidodadi mempunyai AD/RT yang merupakan acuan bagi para anggota dan pengurus untuk melakukan aktivitas organisasi dalam rangka melanjutkan sistem irigasi partisipatif. Sesuai amanat amanat Permen PUPR No.30 Tahun 2007 mengenai Sistem Irigasi Partisipatif, masyarakat lokal diharapkan turut serta dalam mengelola jaringan irigasi di wilayah mereka diwujudkan dengan pembentukan institusi lokal P3A atau yang biasanya di Jawa Timur lebih populer dengan HIPPA. Masalah kelembagaan pertama adalah vakumnya beberapa kegiatan organisasi salah satunya adalah rapat umum anggota. Rapat umum anggota dalam AD/RT diadakan dua kali dalam setahun yaitu biasanya pada awal musim penghujan dan awal musim kemarau. Permasalahan yang kedua adalah iuran anggota yang tidak jalan. Pada umumnya, HIPPA adalah organisasi mandiri yang diharapkan dapat mendanai sendiri jaringan irigasi dengan mengandalkan iuran atau kas dari para anggotanya dan juga jaringan bisnis lainnya. Tetapi nampaknya semua hal tersebut tidak terjadi di HIPPA Sidodadi.

Akibat kelembagaan yang tidak berjalan, membuat partisipasi masyarakat dalam tata kelola irigasi Desa Sumberpucung menjadi rendah. Hal tersebut berdampak pada jaringan irigasi di wilayah mereka sendiri. Operasional dan Pemeliharaan (OP) di jaringan irigasi yang minim membuat jaringan irigasi tak terawat dan rusak. Rusaknya jaringan irigasi nantinya akan berdampak pada pendistribusian air yang kurang maksimal bagi para petani yang ratarata tergabung dalam HIPPA maupun GHIPPA ini. Sehingga dari hal tersebut bisa dikatakan HIPPA Sidodadi tingkat partisipasinya rendah dan berdasarkan indikator dari pemerintah, bisa dikategorikan sebagai HIPPA Pemula. Apalagi selama ini HIPPA Sidodadi sifatnya masih mengikuti dan patuh atas semua usulan dan saran baik itu yang diberikan oleh juru maupun dari pihak pemerintah lainnya. Pengambilan keputusan perihal OP juga tidak ada. SDM yang ada di HIPPA Sidodadi juga masih minim. Pelaksanaan teknis perihal pendistribusian air masih rutin tetapi kalau perihal OP belum berjalan sama sekali.

\section{Relasi Kekuasaan Antar Aktor Irigasi}

Konsep power atau kekuasaan memiliki arti yang abstrak. Kekuasaan merupakan salah satu konsep yang paling sering diperdebatkan sejak tahun 1960- an (Nelson dan Wright, 1995: 7). Kekuasaan dalam konteks partisipasi pembangunan juga memiliki dinamika yang sangat kompleks. Partisipasi kontemporer banyak dipengaruhi oleh ideologi, nilai dari aktoraktor yang berpengaruh seperti institusi internasional seperti Bank Dunia dan badan pembangunan internasional lainnya (hal. 1). Konsep kekuasaan yang dipakai dalam penelitian ini adalah konsep kekuasaan dan partisipasi milik John Gaventa. Mereka menjelaskan tentang keterkaitan kekuasaan dengan partisipasi, tentang bagaimana kekuasaan bisa mempengaruhi implementasi atau hasil dari suatu proyek/program partisipasi (Gaventa, 2006: 23).

Dimensi Spaces, kekuasaan yang ada dalam tata kelola air Desa Sumberpucung ialah closed spaces. Pengambilan keputusan tentang bagaimana sistem irigasi partisipatif berjalan menurut amanat PISP seharusnya berbentuk invited spaces. Aktor-aktor yang bersinggungan dalam tata kelola air diberikan kesempatan untuk mengeluarkan suaranya dalam beberapa bidang sistem irigasi seperti rehab, perbaikan, operasional, dan pemeliharaan jaringan irigasi. Nyatanya pembentukan Komir tak pernah terwujud. Belum terbentuknya Komir menciptakan gap atau jurang pemisah yang cukup jauh antar stakeholder. Sementara stakeholder yang ada dalam tata kelola irigasi ini memiliki kewenangan dan kekuasaan yang berbeda-beda. Pemerintah baik pusat, provinsi, dan daerah bisa dikatakan memiliki kekuasaan yang besar jika mengacu pada konsep kekuasaan Max Weber. Kekuasaan yang dilegitimasi dalam bentuk institusi dan membuat kelompok yang dikuasakan secara sukarela tunduk (petani dan kelompok lokal seperti HIPPA). Padahal seharusnya jika mengacu pada konsep partisipasi 
menurut PISP, masyarakat lokal atau masyarakat marjinal harus diberikan kesempatan untuk ikut dalam penentuan putusan terkait dengan tata kelola irigasi. Tidak hanya masyarakat lokal saja, tetapi juga sektor privat, komunitas, dan aktor lain yang secara langsung bersinggungan dengan sumber daya air di lokasi tersebut.

Komir memiliki peran penting dalam keberlanjutan program PISP tersebut. Komir merupakan salah satu badan dalam tata laksana kelembagaan pengelolaan irigasi yang menjembatani kepentingan bawah agar bisa diteruskan ke tingkat yang lebih tinggi. Pembentukan Komir sendiri sebenarnya terdapat dalam Peraturan Menteri Pekerjaan Umum Nomor 31/PRT/M/2007 tentang pedoman mengenai Komisi Irigasi. Komir memiliki peranan yang cukup penting dalam menjembatani antara kepentingan dari yang terkecil hingga ke atas. Fungsi Komir antara lain, menentukan RTTG, rencana pengaturan air irigasi, perencanaan rehab dan pemeliharaan, penyelesaian konflik antar pengguna jaringan irigasi, dan yang terpenting adalah Komir sebagai forum musyawarah yang melibatkan semua elemen yang berkaitan tata kelola air yang salah satu fungsinya adalah meningkatkan partisipasi masyrakat lokal dalam tata kelola air (PERMEN PUPR 30, 2007).

Akibatnya tipe ruang kekuasaan berubah. Seharusnya tipe ruang kekuasaan invited spaces berubah menjadi closed spaces. Ruang kekuasaan yang ada dalam tata kelola irigasi saat ini lebih bersifat tertutup dan cenderung dikuasai oleh aktor aktor tertentu. Tidak ada tempat bagi ruang partisipasi baru bagi petani untuk menyuarakan pendapat dan aspirasinya, padahal konsep irigasi partisipatif menekankan pada keterlibatan petani dalam pengambilan keputusan bersama stakeholder lainnya Pembentukan Komir sebenarnya unsur penting yang menjadi usulan dari proyek PISP agar sistem irigasi partisipasi ini berkelanjutan. Komir diharapkan memberikan arena baru yang demokratis yang mengakomodasi kekuasaan kekuasaan aktor yang ada dalam sistem irigasi. Ruang partisipasi baru ini diharapkan seperti yang dinyatakan oleh Nelson dan Wright shifting power sehingga ada transfer knowledge ke masyarakat lokal. Inti dari partisipasi adalah memberikan masyarakat yang termarjinalkan kekuasaan untuk memperbaiki dan menentukan kehidupannya. Berarti ada kekuasaan yang harus direlakan sehingga decision-making process tidak lagi terpusat (centralized).

Dimensi selanjutnya adalah bentuk kekuasaan. Terdapat beberapa macam bentuk kekuasaan yang terdapat dalam tata kelola irigasi Desa Sumberpucung. Dalam hubungan antara HIPPA dengan struktur lain seperti Dinas Pengairan, dan Unit Pelayanan Teknis (UPT) Balai Besar Wilayah Sungai (BBWS) Brantas Kementerian Pekerjaan Umum dan Perumahan Rakyat (PUPR) perihal operasional dan pemeliharaan (OP), bentuk kekuasaan ada yang berbentuk visible power dan hidden power. Visible power bisa diartikan bentuk kekuasaan yang diatur secara hukum, memiliki struktur, kewenangan, institusi, dan prosedur dalam penentuan putusan secara jelas. Kekuasaan yang terlihat tercermin pada pembentukan kelembagaan HIPPA yang memiliki struktur, peraturan-peraturan yang mengikat bagi para anggotanya. Sementara bidden power tercermin dalam relasi antar ketiga aktor ini (HIPPA, UPT, dan Dinas Pengairan).

Di HIPPA Sidodadi kekuasaan dan relasi kekuasaan menjadi salah satu penyebab partisipasi minim, dan tidak berjalannya kelembagaan HIPPA. Dalam interaksi sehari-hari dalam tata kelola air di Desa Sumberpucung terdapat relasi kekuasaan antara HIPPA, juru pengairan, pokja, dan pemerintah (dinas pengairan dan UPT BBWS Sungai Brantas). Tetapi sifat relasi kekuasaan ini cenderung menghasilkan hal negatif. Paska PISP berakhir, program pemberdayaan petani berupa peningkatan kapasitas organisasi, peningkatan kemampuan teknis bagi petani lama kelamaan tidak lagi berjalan. Hal itu akhirnya berpengaruh pada kelembagaan HIPPA dan juga mempengaruhi para juru pengairan di wilayah Desa Sumberpucung. Program pemberdayaan sudah lama tidak berjalan sehingga membuat petani kebingungan dan tidak tahu harus berbuat apa dengan organisasi HIPPA ini. 


\section{Individu dan Partisipasi di HIPPA Sidodadi}

Proyek PISP sejatinya sama dengan proyek/program pembangunan yang memakai pendekatan partisipatif yang menekankan pembentukan institusi guna mendukung aktivitas proyek/program. Banyak pendekatan partisipasi pembangunan dari institusi internasional yang mengaitkan partisipasi dengan tanggung jawab sosial (Cleaver, 1999: 606). Mereka seolah menyatakan bahwa tindakan untuk tidak berpartisipasi sebagai tindakan tidak bertanggung jawab dan pada saat yang sama menstereotip bahwa individu akan mendapatkan manfaat langsung yang bersifat jangka panjang, dan kumulatif jika individu ikut berpartisipasi. Faktanya, tidak semua individu secara sukarela ikut berpartisipasi dalam suatu proyek melalui keikutsertaannya dalam suatu institusi karena masing-masing individu memiliki self-interest dan motivasi yang berbeda-beda. Tujuan pembentukan institusi lokal yang ada dalam proyek pembangunan seperti PISP adalah mengurangi biaya transaksi individu, dan menyamakan tujuan (collective action) sehingga individu/masyarakat dapat dikontrol sehingga memaksimalkan hasil proyek pembangunan dianggap Cleaver sesuatu yang kurang tepat.

Meski begitu, Cleaver tidak menyatakan bahwa pembentukan institusi lokal guna mendukung suatu proyek pembangunan adalah sesuatu yang sepenuhnya salah. Ia melihat bahwa pembentukan institusi juga memerlukan analisis faktor faktor lain seperti kultur, agama, relasi kekuasaan, struktur sosial, dan perilaku individu. Namun, pada kenyataannya dalam keanggotaan HIPPA Sidodadi ternyata memiliki self-interest, motivasi, kapasitas dan faktor-faktor seperti insentif, dan willingness yang mempengaruhi partisipasi dalam keanggotaan HIPPA Sidodadi.

\section{Motivasi dan Partisipasi yang Fluktuatif}

Motivasi menurut Cleaver adalah salah satu faktor yang diabaikan oleh para agensi pembangunan dalam menerapkan konsep partisipasinya. Motivasi sering kali dinomorduakan jika dikaitkan dengan partisipasi individu. Individu seolah dikekang oleh norma-norma tanggung jawab sosial, pengabdian masyarakat yang dilegitimasi ke dalam bentuk institusi dengan tujuan memaksimalkan pembangunan ekonomi (hal. 606-607). Nyatanya persepsi seperti itu memberikan tempat yang sedikit bagi faktor-faktor lain seperti motivasi psikologis personal, dan pengakuan atas rasa hormat dan tujuan yang mana menurut Cleaver dalam pengalamannya menjadi alasan bagi individu untuk berpartisipasi atau tidak (hal. 606).

Motivasi individu atau para anggota di HIPPA Sidodadi cenderung sama. Hal tersebut dibuktikan dari hasil wawancara penulis dengan 3 anggota HIPPA Sidodadi, yaitu Pak Jaelani, Pak Aziz, dan Pak Mesenan. Mereka memiliki motivasi yang sama tentang mengapa mereka ikut dalam keanggotaan HIPPA. Motivasi mereka ialah karena kebutuhan. Karena hal tersebut merupakan kebutuhan maka jika mereka tidak ikut berpartisipasi, petak sawah mereka tidak akan mendapatkan air dari saluran tersier. Berarti ini sesuai dengan fungsi institusi yang dibawa oleh agensi pembangunan bahwa pembentukan institusi lokal mau tidak mau membuat individu ikut terlibat di dalamnya bila mereka ingin mendapatkan keuntungan. Tetapi yang menjadi permasalahan, tidak semua anggota HIPPA Sidodadi secara sukarela ikut terlibat dalam memakmurkan organisasi. Maka dari itu, organisasi HIPPA tidak berjalan sebagaimana mestinya disebabkan adanya motivasi tertentu dari masing-masing individu untuk berpartisipasi dalam organisasi HIPPA, seperti ada inspeksi atau survei dari pemerintah dimana para anggota akan mendapatkan pesangon.

Motivasi sampingan tersebut adalah kebutuhan akan kapital. Kapital bisa diartikan sebagai modal yang berbentuk fisik dan berbentuk non-fisik. Dalam kasus ini modal yang dimaksud adalah modal fisik yaitu berupa uang. Hal tersebut juga yang menyebabkan mengapa organisasi HIPPA vakum lebih dari 3 tahun lamanya karena tidak ada perhatian dari pemerintah. Sehingga membuat para anggota HIPPA menganggap organisasi tidak 
terlalu penting bagi aktivitas mereka. Tetapi ada juga menemukan motivasi lain dari para anggota ini mengenai keinginan untuk membuat HIPPA kembali berjalan. Seperti yang dikatakan oleh Pak Aziz bahwa ada perbedaan ketika dulu HIPPA aktif dan ketika HIPPA vakum. Perbedaan itu ialah hal-hal yang bersifat hubungan sosial yang positif seperti kerukunan, keakraban, dan saling percaya antar anggota.

\section{Kapasitas Organisasi Rendah}

HIPPA Sidodadi memiliki aktor yang mempunyai pengaruh atau karismatik yang kuat tetapi tidak memiliki power yang dibutuhkan untuk membawa organisasi lebih maju. Pak Yateno menjadi salah satu figur yang paling dihormati dalam keanggotaan HIPPA Sidodadi. Ia menjadi ketua sejak HIPPA Sidodadi berdiri di tahun 2009. Pemilihan Pak Yateno menjadi ketua HIPPA juga tidak berdasarkan mekanisme seperti pemilihan/voting sesuai amanat dari PISP. Pembentukan institusi lokal seperti HIPPA dan GHIPPA diharapkan menumbuhkan nilai-nilai demokrasi dengan harapan menghindari praktik-praktik negatif Pak Yateno sebagai ketua HIPPA yang menurut anggota HIPPA memiliki kharismatik dan dihormati oleh semua anggota menurut penulis tidak memiliki kapabilitas untuk membawa HIPPA Sidodadi menjadi lebih baik. Hal tersebut tercermin pada relasi kekuasaan yang mana hubungan antara yang berkuasa dan yang dikuasakan terlihat kabur (pengurus HIPPA dengan anggota HIPPA). Hal itu tercermin pada pernyataan salah satu pengurus HIPPA bagian teknis yaitu Pak Manito. Dalam AD/RT HIPPA Sidodadi telah dijelaskan tentang mekanisme pemberian sanksi bagi anggota yang tidak taat. Tetapi nyatanya sanksi tersebut terkesan tidak tegas dan terlihat sebagai pelengkap saja. Hal tersebut tercermin dari pernyataan Pak Manito perihal pemberian sanksi atau hukuman bagi anggota yang melanggar aturan yang ada di HIPPA Sidodadi seperti mencuri air atau tidak membayar iuran seperti kolusi dan kontrol elit tertentu hanya diberi nasehat.

Penjelasan dari Pak Manito sebagai pengurus bidang teknis HIPPA Sidodadi tersebut menjelaskan bahwa penerapan hukuman atau sanksi dalam HIPPA Sidodadi masih belum sepenuhnya tegas. Padahal dalam AD/RT telah dijelaskan bagi mereka yang mencuri air bahwa mereka tidak akan diberikan air bagi petak sawah mereka pada putaran selanjutnya hingga mereka membayar denda seharga satu putaran air tersebut. Power to yang dimiliki pengurus HIPPA tidak terlihat sehingga power over ke anggota HIPPA juga tidak terlihat. Kapasitas dari pengurus HIPPA masih kurang. Hal tersebut tercermin dari sistem jaringan irigasi di wilayah mereka dan juga perihal kelembagaan. Rata-rata anggota HIPPA Sidodadi tidak terlalu mengerti bagiamana memberdayakan organisasi, perilaku organisasi, dan manajemen organisasi. Begitu juga perihal teknis mengenai Peta Skema Operasional (PSO) dan juga Rencana Tata Tanam Guna (RTTG). Selama ini akibat vakum nya aktivitas-aktivitas organisasi seperti rapat anggota umum setiap setahun sekali membuat relasi sosial di dalam HIPPA Sidodadi menjadi kurang atau renggang. Tidak adanya interaksi menciptakan tidak adanya kordinasi yang membuat apa yang tertulis dalam AD/RT HIPPA Sidodadi hanya menjadi bacaan semata.

\section{Partisipasi dan Insentif}

Cleaver menyatakan bahwa pada umumnya masyarakat akan ikut berpartisipasi jika terdapat insentif dalam proyek/program pembangunan tersebut. Fakta yang ada diHIPPA Sidodadi ternyata mengkonfirmasi apa yang dinyatakan Cleaver. Individu di HIPPA Sidodadi ternyata aktif kembali setelah turunnya dana dari pemerintah provinsi yaitu dana P3TGAI. Hal itu dibuktikan dari pernyataan Pak Yateno yang menyatakan bahwa para anggota HIPPA Sidodadi kembali aktif atau mengikuti kegiatan organisasi ketika dana P3TGAI turun ke mereka. Dana tersebut turun dari pemerintah provinsi lewat BBWS Brantas yang didahului aktivitas survei oleh tenaga teknis BBWS Brantas. 
Dari sini dapat dinilai bahwa anggota HIPPA akan ikut berpartisipasi ketika mereka distimulasi oleh kapital. Di HIPPA Sidodadi sendiri masyarakat akan ikut berpartisipasi ketika ada dana masuk terutama dana program teknis maupun kelembagaan seperti P3TGAI. Tetapi ketika tidak ada dana ata program dari pihak eksternal (dinas Kabupaten dan BBWS), masyarakat lebih cenderung untuk tidak aktif dalam keanggotaan HIPPA. Padahal seharusnya sistem irigasi partisipatif sesuai rancangan PISP adalah sebuah proses mobilisasi masyarakat yang melibatkan peran serta masyarakat secara sukarela dan sadar demi kebaikan kehidupan mereka sendiri. Nyatanya di HIPPA Sidodadi masyarakat masih tidak ada kesadaran dan kesukarelaan untuk berpartisipasi dalam organisasi HIPPA. Mereka masih memandang bahwa mereka akan baik-baik saja meskipun tidak aktif dalam organisasi. Tetapi seiring HIPPA vakum selama 3 tahun lamanya, mereka perlahan mulai sadar bahwa memang dibutuhkan keberlanjutan dari apa yang ada dalam HIPPA Sidodadi. Mereka mulai sadar akan pentingnya berorganisasi karena merasakan dampaknya ketika HIPPA aktif dan ketika HIPPA vakum dulu.

\section{KESIMPULAN}

PISP adalah proyek bantuan luar negeri yang didanai oleh Asian Development Bank (ADB) dan Pemerintah Belanda (ADB, 2008: 14). Tujuan utama proyek ini adalah tercapainya desentralisasi pengelolaan sistem irigasi berbasis keberlanjutan dan kenaikan produksi pertanian (hal. 2). Proyek ini menekankan pada peran petani dalam beberapa bagian dalam manajemen sistem irigasi. Tujuannya adalah untuk memberdayakan mereka dan menciptakan efisiensi dalam pengelolaan aset irigasi. Tetapi dibalik keberhasilannya, ternyata memiliki dampak kepada organisasi masyarakat. Setelah proyek berakhir, Himpunan Petani Pemakai Air (HIPPA) malah tidak berkembang. Padahal tujuan sampingan proyek PISP ini ialah memberdayakan petani lewat pembentukan institusi dan organisasi lokal. Akibat HIPPA yang tidak berkembang berakibat pada tata kelola irigasi di daerah tersebut terganggu. Terdapat beberapa faktor yang didapatkan penulis mengenai mengapa organisasi lokal seperti HIPPA tidak bisa berkembang pasca proyek PISP berakhir.

Masalah dan kendala tata kelola air Desa Sumberpucung disebabkan partisipasi individu dalam keanggotaan HIPPA rendah sehingga membuat HIPPA tidak maksimal menerapkan sistem irigasi partisipatif. Sesuai amanat Permen PUPR No.30 Tahun 2007 mengenai Sistem Irigasi Partisipatif, masyarakat lokal (HIPPA) diharapkan turut serta dalam mengelola jaringan irigasi di wilayah mereka. Hal ini dipertegas dari hasil wawancara penulis dengan salah satu staf Dinas Pengairan Kab. Malang bagian Bina Manfaat, Bapak Wawan dan para petani yang tergabung dalam HIPPA Sidodadi yang mengatakan bahwa pembentukan Komir hanya sekedar wacana saja yang tak pernah terealisasi. Akibat tidak terbentuknya Komir, muncul permasalahan lain yaitu peran partisipatif masyarakat dalam pemeliharaan, RTTG, dan pembangunan sistem irigasi yang minim. Partisipasi HIPPA praktis hanya ada pada saat ada kegiatan bina manfaat HIPPA dari Dinas Pengairan dan Dinas Pertanian dan selebihnya HIPPA maupun GHIPPA jarang dilibatkan dalam proses perencanaan dan lainnya. HIPPA seolah hanya dijadikan organisasi bayangan yang harus ada dalam tata kelola air desa jika ingin sistem irigasi mereka mendapat dana baik perbaikan atau pembangunan. Setelah program PISP berakhir di beberapa daerah di Kabupaten Malang, sangat minim peran HIPPA dalam kontribusi tata kelola air di sistem irigasi mereka sendiri.

Alasan lain mengapa partisipasi dalam HIPPA Sidodadi minim dalam tata kelola irigasi Kab. Malang adalah masalah power and structure dan individu. Partisipasi minim akibat pengaruh individu baik itu dari faktor motivasi, kapasitas, dan insentif. Masyarakat di HIPPA Sidodadi cenderung memiliki motivasi yang sama mengapa mereka ikut dalam keanggotaan HIPPA Sidodadi. Tetapi ditemukan juga beberapa orang melihat bahwa 
keanggotaan HIPPA Sidodadi tidak terlalu menguntungkan bagi mereka karena tidak adanya insentif seperti pada saat dana program seperti PISP ada atau dana lain dari pemerintah. Permasalahan lainnya adalah mengenai kapasitas. Organisasi HIPPA menjadi tidak berkembang karena individu tidak memiliki kapasitas yang mumpuni. Hal itu tercermin pada individu yang menjadi pengurus dalam HIPPA Sidodadi. Ada salah satu pengurus yang memiliki karismatik dan dihormati oleh para anggota tetapi lemah dalam memberikan force pada para anggotanya. Pengurus di bagian teknis juga tidak memiliki ketegasan dalam hal menerapkan sanksi dan hukuman sesuai AD/RT kepada para anggota yang melanggar aturan.

\section{DAFTAR PUSTAKA}

Ansori, M. B., Edijatno., \& Soesanto, S. R. (2018). Irigasi dan Bangunan Air. Surabaya: Fakultas Teknik ITS.

Asian Development Bank. (2008). Project Administration Memorandum: Republic of Indonesia Participatory Irrigation Sector Project. Diakses tanggal 1 Mei 2019, dari https://www.adb.org/projects/32359-013/main.

Asian Development Bank. (2011). Completion Report: Indonesia Participatory Irrigation Sector Project. Diakses tanggal 1 Mei 2009, dari https://www.adb.org/projects/32359-013/main.

Asian Development Bank. (2001). Technical Assisatance to The Republic of Indoenesia for Preparaing The Participatory Irrigation Sector Project. 96 Diakses tanggal 1 Mei 2009, dari https://www.adb.org/projects/32359- 013/main.

Asian Development Bank. (2003). Report and Recommendation of The President to The Boards of Directors on Proposed Loans to The Republic of Indonesia for The Participatory Irrigation Sector Project. Diakses tanggal 1 Mei 2009, dari https://www.adb.org/projects/32359-013/main.

Badan Perencanaan Pembangunan Nasional. (2000). Program Pembangunan Nasional 2002004. Jakarta. Diakses tanggal 30 April 2019, dari https://www.Bappenas.go.id/id/data- dan-informasi-tama/dokumenperencanaandan-pelaksanaan/program-pembangunan-nasional-2000- 2004-propenas/.

Badan Perencanaan Pembangunan Nasional. (2005). Rencana Pembangunan Jangka Menengah Nasional Tahun 2004-2009. Jakarta. Diakses tanggal 30 April 2019, dari https://www.Bappenas.go.id/files/9814/2099/2543/RPJMN_2004- 2009.pdf.

Ballabh, V. (2008). Governance of Water Institutional Alternatives and Political Economy.

Carlsnaes, W., Risse, T., \& Simmons, B. A. (2013). Handbook of International Relations. London: Sage Publications.

Cooke, B., \& Khotari, U. (2001). Participation: the New Tyranny?. New York: Zed Books.

Chambers, R. (1995). Paradigm Shifts and The Practice of Participatory Research and Development. London: Intermediate Technology Publications.

Claridge, T. (2004). Designing Social Capital Sensitive Participation Methodologies. Brisbane: Social Capital Research.

Cleaver, F. (1999). Paradoxes of Participation. Journal of International Development, 11, 597-612. Diakses tanggal 20 Juli 2019 dari https://onlinelibrary.wiley.com/doi/abs/10.1002/(SICI)10991328(199906)11:4\%3C597::AID-JID610\%3E3.0.CO;2-Q,

Gaventa, J. (2005). Reflections of the Uses of the 'Power Cube' Approach for Analyzing the Spaces, Places and Dynamics of Civil Society Participation and Engagement. CFP Evaluation Series No 4. 
Gaventa, J. (2006). Finding the Spaces for Change: A Power Analysis. IDS Bulletin 7(37), 23-33.

Halliday, F. (1stEd.). (1994). Rethinking International Relations. London: Macmillan Press.

Hickey, S., \& Mohan, G. (2004). Participation: from tyranny to transformation?. London: Zed Books.

Holcombe, S. (1995). Managing to Empower: The Grameen Bank's Experience of Poverty Alleviation. New Jersey: Zed Books Ltd.

Independent Evaluation ADB. (2016). Performance Evaluation Report: Indonesia Participatory Irrigation Sector Project. Diakses tanggal 20 April 2019, dari https://www.adb.org/sites/default/files/evaluationdocument/159811/files/pperino- irrigation.pdf.

Kementerian Keuangan. (2011). Laporan Pengelolaan Pinjaman dan Hibah Bulan Maret 2011. Diakses tanggal 25 April 2019, dari 97 http://www.djppr.kemenkeu.go.id/uploads/files/dmodata/in/6Publikasi/Lap oranPengelolaan_PH/LapPengelola/an_PH_Semester-I_2011.pdf.

Lane, J. (1995). Non-governmental organisations and participatory development: the concept in theory versus the concept in practice. In 'Power and Participatory Development'. (Ed. S Wright). (Intermediate Technology Publications: London)

Lamont, C. (2015). Research Methods in International Relations. Singapore: Sage Publications.

Luttrell, C. (2007). The Power Cube Explained. Journal of Empowerment Note.3. Intercooperation and Overseas Development Institute.

Mompati T, Prinsen G (2000) Ethnicity and participatory development methods in Botswana: some participants are to be seen and not heard. Development in Practice.

Morgenthau, A. (1962). A Political Theory of Foreign Aid. The American Political Science Review, 56(2). Diakses tanggal 3 Juni, 2019, dari http://www.jstor.org/stable/1952366.95

Peraturan Menteri Pekerjaan Umum Nomor 30/M/2007 tentang Sistem Irigasi Partisipatif Peraturan Menteri Pekerjaan Umum Nomor 31/PRT/M/2007 tentang Pedoman Mengenai Komisi Irigasi

Peraturan Pemerintah No. 20 Tahun 2006 tentang Irigasi

Peraturan Daerah Kabupaten Malang No. 8 tentang Irigasi

Suhardiman, D. (2008). BUREAUCRATIC DESIGNS: The Paradox of Irrigation Management Transfer in Indonesia. Wageningen: Wageningen University.

Sugiyono. (2014). Memahami Penelitian Kualitatif. Bandung: C.V. Alfabeta.

Suhardiman, D. (2013). The Power to Resist: Irrigation Management Transfer in Indonesia. Water Alternatives, 6(1), 25-41. Diakses tanggal 15 Juli, 2019 dari http://www.wateralternatives.org/.

Suhardiman, D., Giordano, M., Rap, E., \& Wegerich, K. (2013). Bureaucratic Reform in Irrigation: A Review of Four Case Studies. Water Alternatives 7(3), 442-463. Diakses tanggal 17 Juli, 2019 dari http:/ /www.wateralternatives.org/.

Summer, A., \& Tribe, M. (2008). International Development Studies: Theories and Methods in Research and Practice. London: Sage Publications.

Tandon, Y. (1stEd.). (2008). Ending Aid Dependence. Nairobi: Fahamu Books. Tarp, F. (2006). Aid and Development. Swedish Economic Policy Review, 13, 9- 61. Uprety, L. (2010). Problems of Participation and Issues of Sustainability in the Public Irrigation Sistem in the Context of Management Transfer: Some Sociological Observations from Eastern Terai, Nepal. Dhaulagiri Journal of Sociology and Anthropology, 4, 41-64. 
Yin, R.K. (2018). Studi Kasus Desain \& Metode. M. Mudzakir (Trans.). Depok: Rajawali Pers 